\title{
Effect of Rhizobium Inoculation on Yield and Nodule Formation of Cowpea
}

\author{
Thiyam Rebika $^{1 *}$ and Nabakishor Nongmaithem ${ }^{2}$ \\ ${ }^{1}$ Department of Genetics and Plant Breeding, Uttar Banga Krishi Viswavidalaya, Pundabari, \\ Cooch Behar-736165, West Bengal, India \\ ${ }^{2}$ Directorate of Research, Central Agricultural University, Imphal-795004, Manipur, India \\ *Corresponding author
}

\begin{tabular}{|c|}
\hline Keywords \\
\hline $\begin{array}{l}\text { Rhizobium } \\
\text { inoculation, } \\
\text { Genotypes of } \\
\text { cowpea, Nodulation }\end{array}$ \\
\hline Article Info \\
\hline $\begin{array}{l}\text { Accepted: } \\
04 \text { October } 2019 \\
\text { Available Online: } \\
10 \text { November } 2019\end{array}$ \\
\hline
\end{tabular}

\section{Introduction}

The growing demand for food associated with rising population has necessitated the increased need for fertilization. But too much reliance on chemical fertilization has led to various environmental hazards as well as the cost of chemical fertilizers is becoming unaffordable for the farmers. Thus in order to make farming system more sustainable, some means are to be evolved to reduce the need for chemical fertilizers, in particular the nitrogen fertilizers. Legume has long been known for their unique ability to enrich the soil through biological nitrogen fixing system in symbiotic association with rhizobial strains.

There is a great possibility to increase production of legume plants by exploiting better colonization of their root and rhizosphere through rhizobial inoculation, which can fix atmospheric nitrogen and protect nature from pollution. Of the several legumes, cowpea is also known for their high 
quality nutritional values and they are strongly dependent on the nitrogen fixation for their nitrogen nutrition.

Rhizobium species invade the root hairs of cowpea and result in the formation of nodules, where free air nitrogen is fixed. These bacteria, which are present in most of the soils, vary in number, effectiveness in nodulation and $\mathrm{N}$-fixation. Although this crop is capable of fixing atmospheric nitrogen through Rhizobium species living in root nodules, however, under the agro-ecological conditions of North Bengal, the nodulation of cowpea is poor and is a major cause of its lower yield. The present study was conducted to assess the relative ability of the three Rhizobium strains viz. RH41, Cowpea 3 and Cowpea 23 for nodulation and subsequent effect on soil nitrogen content and yield in five different genotypes of cowpea.

\section{Materials and Methods}

To evaluate the response of five selected genotypes of cowpea to Rhizobium inoculation, pot experiments were conducted under natural at Uttar Banga Krishi Vishwavidalaya, Pundibari, Cooch Behar during the period 2011 to 2013. The experiment was laid out in Completely Randomized Design (CRD) with two factors viz., genotype and Rhizobium culture.

Five cowpea genotypes viz. Sundari Bangla, Reenu, Lafa Barbati, Baijanti and Kashi Kanchan were sown in the earthen pots $30 \mathrm{~cm}$ height with $30 \mathrm{~cm}$ top and $15 \mathrm{~cm}$ bottom diameter. The pots were filled with $5 \mathrm{~kg}$ dry sandy loam soil with minimum water holding capacity of the experimental site and sterilized by autoclaving at $121^{\circ} \mathrm{C}$ temperature and 15 psi pressure for 30 minutes.

Three peat based Rhizobium strains viz. RH41, Cowpea 3 and Cowpea 23 used in the experiment were collected from Nodule Research Laboratory, Bidhan Chandra Krishi Viswavidyalaya, Nadia, West Bengal. Seeds of Vigna unguiculata with uniform shape, size and weight were surface sterilized with $3 \%$ sodium hypo chloride solution for 10 minutes followed by 4 washings with sterilized water. For inoculation, the seeds were moistened with a small amount of water and pelted with peat based Rhizobium containing $10^{7}$ per gram with concentrated sugar solution as an adhesive. Ten (10) seeds were sown in each sterilized pots following drying. A basal dose of $20 \mathrm{mg} \mathrm{kg}^{-1} \mathrm{~N}$ as urea, $30 \mathrm{mg} \mathrm{kg}^{-1} \mathrm{P}_{2} \mathrm{O}_{5}$ as triple super phosphate and $30 \mathrm{mg} \mathrm{kg}^{-1} \mathrm{~K}_{2} \mathrm{O}$ as potassium sulphate was applied before sowing. Un-inoculated plants with $\mathrm{N}$ fertilizer.and without $\mathrm{N}$-fertilizer were included for comparison.

During the course of the experiment, growth and developments of plants in the pot were carefully observed. Intercultural operations and other management practices were done as per requirements. Nodulation was recorded during 45 days after sowing (DAS) at 50\% flowering stage by selecting five plants from each pot at random. The plants were up-rooted taking care not to disturb the roots and root hairs. They were washed under running tap water. The number of nodules per plant was counted after which the nodules were carefully removed from the roots and their fresh weight recorded. The data regarding nitrogen content in soil and grain yield/plant were recorded after the harvest of the crop at physiological maturity. Observations were recorded on five plants in each replication. Total nitrogen content of the soil after the harvest of the crop was determined by modified Kjeldhal method. The collected data were subjected to statistical analysis using Fisher's analysis of variance techniques. Duncan's Multiple Range (DMR) Test (Steel \& Torrie, 1980) was used to compare the differences among treatment means.. 


\section{Results and Discussion}

Table 1 represents data on nodulation, nodule weights and root weights of the five cultivars as influenced by the different Rhizobium strains. Nodulation data was recorded at flowering stage because at maturity most of the nodules were disintegrated and decomposed. Seed inoculation significantly affected number of nodules and the treatments significantly differed from each other as compared to the control. The highest nodule number per plant (166 and161.34 plant $^{-1}$ ) and nodule weight $(1142.11$ and $1131.23 \mathrm{mg}$ plant $^{-1}$ ) were recorded by the genotype Kashi Kanchan in the year 2011-2012 and 20122013 respectively in response to Rhizobium culture RH41. The same culture also produced the maximum value for nodulation in the remaining varieties except in Lafa Barbati where the highest value of nodulation was observed with the inoculation of the Rhizobium strain cowpea 3. Nodulation in terms of nodule number and nodule fresh biomass was observed lower in control with nitrogen fertilizer. Similar kinds of observations were reported by Subasinghe et al.,(2001) and Oteino et al.,(2009) who revealed the inhibitory effect of nitrogen fertilizer on nodule formation in grain legumes and cowpea respectively. For the character root weight, the maximum value (3.57 and $3.35 \mathrm{~g}$ plant $^{-1}$ ) was recorded by the inoculated Kashi Kanchan variety with the culture cowpea 23 in the year 2011-2012 and 20122013 respectively.

Data regarding shoot weight, seed yield and $\mathrm{N}$-content in soil after the harvest of the crop was presented in Table 2. The maximum shoot weight was observed by the inoculation of culture RH 41 in all the cowpea genotypes where the highest value was recorded by the variety Reenu (11.32 and $10.92 \mathrm{~g} \mathrm{plant}^{-1}$ ) in the year 2011-2012 and 2012-2013 respectively. When the seed yield per plant was considered the inoculant RH41 was observed to produced maximum yield in four of the five cowpea genotypes under investigation where the highest seed yield ((17.99 and $\left.17.67 \mathrm{~g} \mathrm{plant}^{-1}\right)$ was recorded in the cultivar Sundari Bangla in the year 20112012 and 2012-2013 respectively. The lowest seed yield (12.12 $\left.\mathrm{g} \mathrm{plant}^{-1}\right)$ was observed in un-inoculated Reenu variety without Nfertilizer. These results are in line with the findings of Pawar and co-workers(1998) and Giri et al.,(2010)who reported that seed inoculated plants exhibited significantly greater number of nodules per plant, root weight, shoot weight and seed yield as compared to un-inoculated control plants in chickpea. The results pertaining to soil $\mathrm{N}$ content after harvest showed significant interaction between the treatments and varieties. The investigation showed that almost all the Rhizobium strains significantly improved the soil $\mathrm{N}$ contents after harvesting of the crop except the culture RH 41. Maximum soil N-content $(0.21 \%)$ were recorded in the variety Sundari Bangla and Kashi Kanchan with the seed inoculation of Rhizobium culture cowpea 3 while minimum value were observed in case of control without $\mathrm{N}$-fertilizer. Similar results were reported Rshid et al., (1999) and Zammurad et al., (2008) who found that soil N-content was significantly affected by Rhizobium inoculation.

On the basis of this study, it is concluded that inoculation of seed with Rhizobium significantly affected the nodule formation of cowpea as well as $\mathrm{N}$-content of soil which consequently led to improved soil fertility and can reduce the production cost of next crop through reduced input in the form of $\mathrm{N}$ fertilizers, which in turn also minimize the health hazard effects. Rhizobium inoculation was found to be more effective and produced better yield when compared with no inoculation. 
Table.1 Effects of inoculation on nodulation and root weight of selected cowpea genotypes

\begin{tabular}{|c|c|c|c|c|c|c|}
\hline \multirow[t]{2}{*}{ Treatment } & \multicolumn{2}{|c|}{ Nodule no. per plant } & \multicolumn{2}{|c|}{ Nodule weight (mg plant $\left.{ }^{-1}\right)$} & \multicolumn{2}{|c|}{ Root weight $\left(\right.$ g plant $\left.^{-1}\right)$} \\
\hline & 2011-12 & $2012-13$ & $2011-12$ & $2012-13$ & 2011-12 & $2012-13$ \\
\hline Sundari Bangla $x$ UWN & $40.13 d$ & $39.08 \mathrm{~d}$ & $162.14 d$ & $155.20 \mathrm{e}$ & $2.79 b$ & $2.65 b$ \\
\hline Sundari Bangla $x$ UN & $30.01 \mathrm{e}$ & $27.32 d$ & $80.34 \mathrm{NS}$ & 79.32NS & $1.32 \mathrm{c}$ & $1.26 \mathrm{c}$ \\
\hline Sundari Bangla x RH41 & $100.00 \mathrm{~b}$ & $95.34 b$ & $905.00 \mathrm{a}$ & $897.00 b$ & $2.20 \mathrm{~b}$ & $1.13 \mathrm{c}$ \\
\hline Sundari Bangla $x$ cowpea 3 & $95.12 b$ & $90.22 b$ & $759.11 b$ & $747.55 b$ & $3.10 \mathrm{a}$ & $3.00 \mathrm{a}$ \\
\hline Sundari Bangla $x$ cowpea 23 & $78.32 \mathrm{c}$ & $72.34 \mathrm{c}$ & $749.10 \mathrm{~b}$ & $638.24 c$ & $3.08 \mathrm{a}$ & $2.98 \mathrm{a}$ \\
\hline Reenu x UWN & $37.00 \mathrm{e}$ & $33.66 \mathrm{e}$ & $100.23 e$ & $92.43 f$ & $1.57 \mathrm{c}$ & $1.43 \mathrm{c}$ \\
\hline Reenu x UN & $33.23 \mathrm{e}$ & $27.43 e$ & $56.10 \mathrm{NS}$ & $44.56 \mathrm{NS}$ & $1.99 b$ & $1.79 \mathrm{c}$ \\
\hline Reenu x RH41 & $77.50 \mathrm{c}$ & $72.50 \mathrm{c}$ & $611.13 b$ & $595.53 c$ & $2.47 b$ & $2.25 b$ \\
\hline Reenu x cowpea 3 & $59.00 \mathrm{~d}$ & $53.00 \mathrm{~d}$ & $374.00 \mathrm{c}$ & $362.00 \mathrm{~d}$ & $1.30 \mathrm{c}$ & $1.14 \mathrm{c}$ \\
\hline Reenu x cowpea 23 & $50.00 \mathrm{~d}$ & $45.34 d$ & $435.00 \mathrm{c}$ & $423.00 d$ & $1.10 \mathrm{c}$ & $0.90 \mathrm{~d}$ \\
\hline Lafa Barbati x UWN & $36.24 \mathrm{e}$ & $32.42 \mathrm{e}$ & $120.00 \mathrm{e}$ & $110.13 \mathrm{e}$ & $1.05 \mathrm{c}$ & $0.93 d$ \\
\hline Lafa Barbati x UN & $40.00 \mathrm{~d}$ & $38.00 \mathrm{e}$ & $239.22 d$ & $223.44 \mathrm{e}$ & $1.40 \mathrm{c}$ & $1.26 \mathrm{c}$ \\
\hline Lafa Barbati x RH41 & $71.14 \mathrm{c}$ & $67.52 b$ & $600.34 b$ & $593.00 \mathrm{c}$ & $1.34 \mathrm{c}$ & $1.14 \mathrm{c}$ \\
\hline Lafa Barbati x cowpea 3 & $75.13 c$ & $71.53 \mathrm{c}$ & $783.00 \mathrm{~b}$ & $769.00 \mathrm{~b}$ & $2.20 \mathrm{~b}$ & $2.04 \mathrm{~b}$ \\
\hline Lafa Barbati x cowpea 23 & $65.00 \mathrm{c}$ & $61.00 \mathrm{c}$ & $549.11 \mathrm{c}$ & $534.23 \mathrm{c}$ & $3.18 \mathrm{a}$ & $2.98 \mathrm{a}$ \\
\hline Baijanti x UWN & $47.00 \mathrm{~d}$ & $43.00 \mathrm{~d}$ & $340.00 \mathrm{~d}$ & $322.00 d$ & $1.58 \mathrm{c}$ & $1.36 \mathrm{c}$ \\
\hline Baijanti x UN & $33.00 \mathrm{e}$ & $29.00 \mathrm{~d}$ & $193.00 \mathrm{e}$ & $183.00 \mathrm{e}$ & $1.47 \mathrm{c}$ & $1.29 \mathrm{c}$ \\
\hline Baijanti x RH41 & $164.00 \mathrm{a}$ & $156.00 \mathrm{a}$ & $1132.00 \mathrm{a}$ & $1034.66 \mathrm{a}$ & $3.33 \mathrm{a}$ & $3.13 \mathrm{a}$ \\
\hline Baijanti x cowpea 3 & $71.00 \mathrm{c}$ & $63.00 \mathrm{c}$ & $570.24 c$ & $554.42 c$ & 1.56 & $1.34 \mathrm{c}$ \\
\hline Baijanti x cowpea 23 & $61.00 \mathrm{c}$ & $55.00 \mathrm{~d}$ & $529.11 \mathrm{c}$ & $513.55 \mathrm{c}$ & $2.65 b$ & $2.35 b$ \\
\hline Kashi Kanchan x UWN & $68.00 \mathrm{c}$ & $62.00 \mathrm{c}$ & $336.34 d$ & $324.32 d$ & $1.36 \mathrm{c}$ & $1.20 \mathrm{c}$ \\
\hline Kashi Kanchan x UN & $34.33 \mathrm{e}$ & $28.00 \mathrm{e}$ & $100.00 \mathrm{e}$ & $91.34 \mathrm{f}$ & $1.64 \mathrm{c}$ & $1.38 \mathrm{c}$ \\
\hline Kashi Kanchan x RH41 & $166.00 \mathrm{a}$ & $161.34 \mathrm{a}$ & $1142.11 \mathrm{a}$ & $1131.23 \mathrm{a}$ & $1.76 \mathrm{c}$ & $1.52 \mathrm{c}$ \\
\hline Kashi Kanchan $x$ cowpea 3 & $98.00 \mathrm{~b}$ & $92.00 \mathrm{~b}$ & $741.00 \mathrm{~b}$ & $732.34 b$ & $2.00 \mathrm{~b}$ & $1.84 \mathrm{c}$ \\
\hline Kashi Kanchan x cowpea2 3 & $94.00 \mathrm{~b}$ & $88.00 \mathrm{~b}$ & $680.00 b$ & $660.00 \mathrm{c}$ & $3.57 \mathrm{a}$ & $3.35 \mathrm{a}$ \\
\hline S.E.(m) & 6.59 & 5.99 & 76.18 & 75.00 & 0.20 & 0.18 \\
\hline
\end{tabular}

Means followed by common letter are not significantly different at 5\% DMRT

$\mathrm{NS}=$ non-significant, $\mathrm{UWN}=$ un-inoculated without nitrogen, $\mathrm{UN}=\mathrm{Un}$-inoculated with nitrogen 
Table.2 Effects of inoculation on shoot weight, seed yield and N-content in the selected cowpea genotypes

\begin{tabular}{|c|c|c|c|c|c|c|}
\hline \multirow[t]{2}{*}{ Treatment } & \multicolumn{2}{|c|}{ Shoot weight $\left(\right.$ g plant $\left.^{-1}\right)$} & \multicolumn{2}{|c|}{ Seed yield $\left(g_{\text {plant }}{ }^{-1}\right)$} & \multicolumn{2}{|c|}{$\mathrm{N}$ content in soil $(\%)$} \\
\hline & $2011-12$ & $2012-13$ & 2011-12 & $2012-13$ & 2011-12 & $2012-13$ \\
\hline Sundari Bangla x UWN & $5.00 \mathrm{c}$ & $4.80 \mathrm{~d}$ & $15.10 \mathrm{~b}$ & $14.78 \mathrm{~b}$ & $0.11 \mathrm{c}$ & $0.10 \mathrm{~d}$ \\
\hline Sundari Bangla $\mathrm{x}$ UN & $6.54 \mathrm{c}$ & $6.10 \mathrm{c}$ & $16.00 \mathrm{a}$ & $15.18 \mathrm{~b}$ & $0.13 c$ & $0.11 \mathrm{c}$ \\
\hline Sundari Bangla x RH41 & $9.30 \mathrm{a}$ & $9.08 \mathrm{a}$ & $17.99 \mathrm{a}$ & $17.67 \mathrm{a}$ & $0.12 \mathrm{c}$ & $0.10 \mathrm{c}$ \\
\hline Sundari Bangla $x$ cowpea 3 & $7.86 \mathrm{~b}$ & $7.42 \mathrm{~b}$ & $17.80 \mathrm{a}$ & $17.54 \mathrm{a}$ & $0.21 \mathrm{a}$ & $0.19 a$ \\
\hline Sundari Bangla $x$ cowpea 23 & $6.81 \mathrm{c}$ & $6.33 c$ & $16.32 \mathrm{a}$ & $16.10 \mathrm{a}$ & $0.18 \mathrm{a}$ & $0.16 b$ \\
\hline Reenu x UWN & $6.79 \mathrm{c}$ & $6.35 c$ & $13.30 \mathrm{c}$ & $12.12 \mathrm{c}$ & $0.11 d$ & $0.10 \mathrm{~d}$ \\
\hline Reenu x UN & $8.00 \mathrm{~b}$ & $7.76 b$ & $15.78 b$ & $15.35 b$ & $0.15 b$ & $0.13 \mathrm{c}$ \\
\hline Reenu x RH41 & $11.32 \mathrm{a}$ & $10.92 \mathrm{a}$ & $16.40 \mathrm{a}$ & $16.20 \mathrm{a}$ & $0.12 \mathrm{c}$ & $0.10 \mathrm{~d}$ \\
\hline Reenu x cowpea 3 & $6.70 \mathrm{c}$ & $6.00 \mathrm{c}$ & $15.60 \mathrm{~b}$ & $15.40 \mathrm{~b}$ & $0.17 \mathrm{a}$ & $0.15 b$ \\
\hline Reenu $x$ cowpea 23 & $5.91 \mathrm{c}$ & $5.31 \mathrm{c}$ & $16.55 a$ & $16.25 \mathrm{a}$ & $0.18 \mathrm{a}$ & $0.16 b$ \\
\hline Lafa Barbati x UWN & $6.76 c$ & $6.10 \mathrm{c}$ & $13.75 \mathrm{c}$ & $13.53 \mathrm{c}$ & $0.11 \mathrm{~d}$ & $0.10 \mathrm{~d}$ \\
\hline Lafa Barbati x UN & $6.67 \mathrm{c}$ & $6.23 \mathrm{c}$ & $13.55 \mathrm{c}$ & $13.25 \mathrm{c}$ & $0.14 \mathrm{c}$ & $0.12 \mathrm{c}$ \\
\hline Lafa Barbati x RH41 & $9.45 \mathrm{a}$ & $8.93 b$ & $17.45 a$ & $17.29 \mathrm{a}$ & $0.12 c$ & $0.10 \mathrm{~b}$ \\
\hline Lafa Barbati $x$ cowpea 3 & $5.50 \mathrm{c}$ & $5.06 \mathrm{c}$ & $17.08 \mathrm{a}$ & $16.90 \mathrm{a}$ & $0.18 \mathrm{a}$ & $0.16 b$ \\
\hline Lafa Barbati x cowpea 23 & $7.49 \mathrm{~b}$ & $7.03 b$ & $14.22 \mathrm{~b}$ & $14.12 \mathrm{~b}$ & $0.20 \mathrm{a}$ & $0.18 \mathrm{a}$ \\
\hline Baijanti x UWN & $5.24 \mathrm{c}$ & $8.14 b$ & $13.31 \mathrm{c}$ & $13.11 \mathrm{c}$ & $0.11 \mathrm{~d}$ & $0.10 \mathrm{~d}$ \\
\hline Baijanti x UN & $8.52 b$ & $4.90 \mathrm{~d}$ & $13.84 \mathrm{c}$ & $13.66 \mathrm{c}$ & $0.15 b$ & $0.13 \mathrm{c}$ \\
\hline Baijanti x RH41 & $10.09 \mathrm{a}$ & $9.77 \mathrm{a}$ & $15.90 \mathrm{~b}$ & $15.76 \mathrm{~b}$ & $0.12 \mathrm{c}$ & $0.10 \mathrm{~d}$ \\
\hline Baijanti x cowpea 3 & $7.41 \mathrm{~b}$ & $7.17 \mathrm{~b}$ & $14.40 \mathrm{~b}$ & $14.22 \mathrm{~b}$ & $0.18 \mathrm{a}$ & $0.16 b$ \\
\hline Baijanti x cowpea 23 & $7.67 \mathrm{~b}$ & $7.13 b$ & $13.28 \mathrm{c}$ & $13.16 \mathrm{c}$ & $0.16 b$ & $0.14 \mathrm{c}$ \\
\hline Kashi Kanchan x UWN & $5.60 \mathrm{c}$ & $5.12 \mathrm{c}$ & $13.29 \mathrm{c}$ & $13.15 \mathrm{c}$ & $0.11 d$ & $0.10 \mathrm{~d}$ \\
\hline Kashi Kanchan x UN & $8.00 \mathrm{~b}$ & $7.74 b$ & $14.95 b$ & $14.85 \mathrm{~b}$ & $0.13 c$ & $0.11 \mathrm{c}$ \\
\hline Kashi Kanchan x RH41 & $9.11 \mathrm{a}$ & $8.83 b$ & $17.80 \mathrm{a}$ & $17.64 a$ & $0.13 c$ & $0.11 \mathrm{c}$ \\
\hline Kashi Kanchan x cowpea 3 & $5.52 \mathrm{c}$ & $5.18 \mathrm{c}$ & $16.00 \mathrm{a}$ & $15.88 \mathrm{~b}$ & $0.21 \mathrm{a}$ & $0.19 \mathrm{a}$ \\
\hline Kashi Kanchan $x$ cowpea 3 & $8.00 \mathrm{~b}$ & $7.62 b$ & $16.45 a$ & $16.35 a$ & $0.18 \mathrm{~b}$ & $0.16 \mathrm{~b}$ \\
\hline S.E. $(\mathrm{m})$ & 0.69 & 0.61 & 0.60 & 0.56 & 0.011 & 0.009 \\
\hline
\end{tabular}

Means followed by common letter are not significantly different at 5\% DMRT

$\mathrm{NS}=$ non-significant, $\mathrm{UWN}=$ un-inoculated without nitrogen, $\mathrm{UN}=\mathrm{Un}$-inoculated with nitrogen

Among the Rhizobium strain, the culture RH41 was found to be the most promising one for inoculation in the cowpea genotype as it proved its efficiency in nodulation and yield quality in almost all the varieties under investigation. More field trial is imperative in the agro-ecological regions of Pundibari District (West Bengal) to confirm these findings.

\section{References}

Abusuwar, A.O. and Omer, E.A. 2011. Effect of intercropping, phosphorus fertilization and rhizobium inoculation on the growth and nodulation of some leguminous and cereal forages. Agriculture and Biology Journal of North America 2(1): 109-124.

Eusuf Zai, A.K., A.R.M. Solaiman and J.U. Ahmed. 1999. Response of some chickpea varieties to Rhizobium inoculation in respect of nodulation, biological nitrogen fixation and dry matter yield. Bangladesh Journal of Microbiology 16(2): 135-144.

Ferreira, E.P. de. B., Martins, L.M.V., Xavier, G.R. and Rumjanek, N.G. 2011. 
Nodulation and grain yield by cowpea (Vigna unguiculata L. Walp.) inoculated with rhizobia isolates. Revista Caatinga 24(4): 27-35

Giri, N and Joshi, N.C. 2010. Growth and yield response of chickpea (Cicer arietinum) to seed inoculation with $c$ sp. Nature and Science 8(9): 232-236.

Hungaria, M., L.H. Boddey. M.A. Santos and M.A.T. Vargas. 1998. Nitrogen fixation capacity and nodule occupancy by Bradyrhizobium japonicum and B. Elkanii strains. Biology and Fertility of Soils 27: 393399.

Khanam, D., Bhuiyan M.A.H., Rahman M.H.H. and Hossain A.K.M.. 1999. On-farm experience of the application and adoption of biological nitrogen fixation technology in Bangladesh. Bangladesh Journal of Agricultural Research 24(2): 375-382.

Ali M.E., Khanam D., Bhuiyan M.A.H., Khatun M.R. and Talukder M.R.. 2008. Effect of Rhizobium inoculation to different varieties of gardenpea. Journal of Soil Nature. 2(1): 30-33.

Otieno, P.E., Muthomi, J.W., Chemining'wa, G.N. and Nderitu, J.H. 2009. Effect of Rhizobia inoculation, farm yard manure and nitrogen fertilizer on nodulation and yield of food grain legumes. Journal of Biological Science 9(4): 326-332.

Pawar, K.B., Bendre, N.L., Desmukh, R.B. and Perane, R.R. 1998. Field response of chickpea seed inoculation of Rhizobium strains to nodulation and grain yield. Journal of Maharashtra Agricultural Universities. 22(3): 370371.

Rashid, A., M. Musa, N.K. Adal, M. Yaqub and G.A. Chaudary, 1999. Response of groundnut to Bradyrhizobium and Diazotroph bacterial inoculum under different levels of nitrogen. Pakistan Journal Soil, 16: 89-98.

Subasinghe, S. Dayathilake, G.A. and Senaratne, R. 2001. Effect of inoculation and $\mathrm{N}$ application on growth, yield, nodulation and $\mathrm{N}$ fixation of cowpea (Vigna unguiculata). Tropical Agricultural Research and Extension 4(2): 108-111.

Zammurad I.A., Muhammad A., Muhammad T. And Muhammad S. A. 2008. Effect of different Rhizobium inoculation methods on performance of lentil in Pothowar Region. International Journal of Agriculture and Biology, 10(1): 81-84.

\section{How to cite this article:}

Thiyam Rebika and Nabakishor Nongmaithem. 2019. Effect of Rhizobium Inoculation on Yield and Nodule Formation of Cowpea. Int.J.Curr.Microbiol.App.Sci. 8(11): 134-139. doi: https://doi.org/10.20546/ijcmas.2019.811.016 